\title{
HUMAN RELATIONSHIPS IN CHARLES DICKENS' BLEAK HOUSE
}

\author{
K. SHANTIKUMAR SHARMA ${ }^{1} \&$ H. SHIMREINGAM ${ }^{2}$ \\ ${ }^{I}$ Research Scholar, Department of English, CMJ University, Meghalaya, India \\ ${ }^{2}$ Research Scholar \& Assistant Professor, Department of English, \\ Pettigrew College, Ukhrul, Govt. of Manipur, India
}

\begin{abstract}
The top writer of the Victorian Age, Charles Dickens created human relationships and took deep attention in representing the London city life and its desire in his novels. Many types of relations i.e. the relationship between the lovers, servant and Master, boarders and caretaker, friends, etc. are dealt in the novel. He had the life experiences in the London streets for which he was viewed as the first honest story teller. He not only came up at the right time in the English novel history on the literary side but also on the other the social problems. In his novels, he took about all classes of people living in various social levels which the London city had during the reign of Queen Victoria and relationships between people. The writer sensitively drawn all segments of society including children and women who struggled for survival and existence for rightest in the London society. And he never attempts to change the evidences to go fine with the present values of society. The article speaks about Dickens' human relationships and realize how he keeps the associations among the characters which have existed in the Victorian society.

KEYWORDS: Charles Dickens, Victorian Age, London Streets, Portrayal, Human Relationship, Struggle \& Survival for Fittest
\end{abstract}

Received: Jun 25, 2018; Accepted: Jul 14, 2018; Published: Aug 29, 2018; Paper Id.: IJELOCT20182

\section{INTRODUCTION}

Charles Dickens was born on $7^{\text {th }}$ February 1812 . His mom privately taught him. The novels he obtained from his father comprises: Humphry Clinker, Roderick Random, Tom Jones, Don Quixote, The Vicar of Wakefield, Robinson Crusoe, etc. When the family met with monetary crisis, a friend of John Dickens gave his son, Charles Dickens work in a blacking profession at Hungerford Stairs where Charles begun to work at the age of twelve, by bottles labelling for six shillings a week. There, he suffered intolerable mental stress for the untrained work of labelling and washing blacking bottles. John Dickens was taken to the Marshalsea Debtor's Prison for debt. Charles Dickens used to spend his Sundays with his dad in the jail and at the warehouse on other days as usual. After 3 months of custody, his father was released on the receipt of a bequest from his mom, who died keeping a sum of 450pounds for him. Few weeks later, John Dickens extracted Charles from his work and sent him to school. Again, at the age fifteen, Charles Dickens started to work in Gray's Inn attorneys. These painful experiences in life form the backdrop for the making of his children characters. Meanwhile, he trained himself in shorthand and started to work as a freelance journalist in the court of Doctors' Commons.

\section{BLEAK HOUSE}

Bleak House (1851-53) was issued in 19 monthly sections and appeared in the issue form before 1853 end. In the novel, we can see the lovely relations between characters such as ada, Allan Woodcourts, Esther 
Summerson, Jarndyce, Rechards, etc., which are attractively outlined by the novelist portraying social exploitations. It is a great novel based upon an actual case in Chancery in which there are postponements and dishonesty of the chancery courts. J. Hillis Miller remarks:

"For Dickens, the world is one unified whole, and if the relations between one man and another and between man and the world are not beneficent, they will be harmful. No man can cut himself off from the world and from other people. At first apparently a world of truncated fragments, Bleak House turns out to be a world in which everything is intimately connected with everything else, both temporarily and spatially. Even people who seem to be separated by great gulfs of space, time, or social status actually have the most decisive effect on one another's lives. The world of Bleak House is a vast interlocking system in which any action or change in one place will have a corresponding and reciprocal effect on every other place."

(Miller: 206)

Again, in the novel's introduction, J.Hillis Miller remarks: "Bleak House is a model of English society in yet another way. The network of relations among various characters is a miniature version of the interconnectedness of people in all levels of society."

(Bleak House: 12)

W. R. Goodman remarks: "A satire on the method of an English equity court Bleak House is a great novel based upon an actual case in Chancery. The story of lives sacrificed on the rack of a meaningless judicial system is an arresting one."

(Goodman: 383)

In this novel, Esther Summerson, the character is the narrator. "Esther of Bleak House is perhaps the subtlest of Dickens' heroines."

(Mei Chin: 67)

She was a very small girl who spoke to toys as she had been alone. She was raised up like few of the princess in the fairy tales by Miss Barbarry, her godmother, who never smiled and was a very stern female. For her godmother, Esther remarks:

"She was always grave, and strict. .......I felt I must have loved her if I had been a better girl."

(Bleak House: 63)

Esther was an orphan and was raised up by Miss Barbarry. She did not know the seriousness where her parents were concealed. She had never been trained to request for any relation except her godmother. She was studying in a school as a day boarder. She knew few girls who are studying in the same school "but she knew none of them at home." (ibid: 63) She was called little Esther Summerson. "Esther is a beautiful, and despite her protests to the contrary she perfectly aware of the fact. Unlike most Dickens' virginal heroins, she is away of the admiration ...."

(Mei Chin: 68) 
Esther's godmother was a stern lady. She never had love for her, but she should love her for she had been raised only by the godmother. She did not even know of any bond between the godmother and her. She came to know the godmother's true face after the godmother died in an accident. For more than a week, she was lying upon her bed after the incident. Esther was by her side while the godmother was lying upon the bed and she felt in her heart to love her godmother. When she found her godmother died finally, she was immovable and still. Esther narrated:

"I kissed her, thanked her, prayed for her, asked her for her blessing and forgiveness, and ........To the very last, and even afterwards, her frown remained unsoftened."

(Bleak House: 67)

Esther and the godmother's relationship is seen in the story as a personal connection and it is significant because Esther got a maternal care from her godmother as she was an orphan. At last, she came to know that her godmother was her true aunt as told by Mr. Kenge. After this incident, Esther was presented to have place her first - rate the institution by one Mr. Jarndyce of Bleak House where her schooling would be over. She had been raised in hand directly under an utmost care of Mr. Jarndyce as her only protector.

\section{Richard and Ada}

There is one more relationship found between Ada and Richard in the novel. They also stayed with Esther in the same house. Richard Carstone was Ada's cousin and she was also a cousin of Mr. Jarndyce. Richard was a handsome, young gentleman of about 19 years of age with an innocent face, and a most attractive laugh. But Richard Carstone and Ada Clare were orphans. Esther Summerson was first acknowledged by Ada after Mr. Kenge presented her to live together.

Ada Clara's first impression is recounted by Esther thus:

"They both looked up when I came in, and I saw in the young lady, ........With such a rich golden hair, such soft blue eyes, and such a bright, innocent, trusting face!"

(ibid: 78)

Esther was presented to them by Mr. Kenge that she was Miss Summerson. Then, they came to meet her with a welcome smile. Ada extended her hand to Esther and kissed her. The three lived together. On an evening, Esther observed:

"that Ada and Richard were more than ever attached to each other's society; which was but natural, seeing they were going to be separated so soon."

(ibid: 228)

Ada's love for Richard is a secret love but she wanted to say this to Esther about her feeling for Richard. She told Esther:

“My darling Esther!' murmured Ada. 'I have a secret to tell you!'....... 'that he loves me dearly, Esther.”

(ibid: 229)

Richard's love for Ada was enormous on the other hand, he said that 
"He would work his fingers to the bone for Ada, and Ada said that she would work her fingers to the bone for Richard."

(ibid: 230)

They three lived together and they shared everything they had. Esther desired giving her promise to talk to their cousin John Jarndyce, her guardian about their relationship. On the other side, she also once had a secret love for Richard before Richard and Ada fell in love. Since it was a secret love, which was not revealed to anybody even to her most loving friend, Ada. She narrated:

"I believed Richards was frank and generous a nature as there possibly can be. and scarcely less pleased with the pretty dream."

(ibid: 165)

Then, Esther told John Jarndyce about the relationship between Richard and Ada. She said her guardian that Richard and Ada were in love. Mr. Jarndyce had also recognized that they were in love, and counselled them:

"Never separate the two, like the heathen waggoner-......That's the end of my preaching, I think you and Ada had better take a walk!”

(ibid: 232-233)

As a protector, Mr. Jarndyce looked after them. Thus, Ada and Richard's love had been confirmed by disclosing before their guardian and cousin. Mr. Jarndyce had observed the same by Esther and their cousin. This type of relationship between Richard and Ada is a very important relationship in the story.

\section{Ada and Esther}

The relationship between Esther and Ada is that of true friendship. Since the day, when Esther was received very warmly by Ada, they developed a true friendship. Both were orphans and they shared their emotions and helped each other. Though, Esther had a secret love for Richard, she forewent her feeling, but she would rather help them making an unbreakable and tight bond between Richard and Ada. When Richard was about to go to pursue his career, Esther was the only charge of Ada with great love for her. She narrated:

"I was a part of all their plans, for the present and the future. I was to write to Richard once a week, making mu faithful report of Ada, .......I was to keep all the keys of their house, I was to be made happy for ever and a day.”

(ibid: 234)

Such type of relations among friends seen in the novel is missing in the real life which the writer would like to impart in the youngsters' minds of the Victorian Age.

\section{Esther and Lady Dedlock}

There is again another relationship found between Lady Dedlock and Esther. When Esther walked along the forest, she met Lady Dedlock, who was her real mother and her godmother, Miss Barbary by name, was her mother's Spartan sister. She was not aware that Miss Barbary was her aunt when she was alive. She never anticipated that her 
mother would have been alive. Actually, Esther was an illegal child of Captain Hawdon and Lady Dedlock, who was her lover before she married Sir Leicester Dedlock. This is the reason why she (Esther) was told by her godmother that she was never born and so she had no birthday like others. Taylor Stoehr remarks about Lady Dedlock:

"The function of Lady Dedlock's self - control is to conceal her passionate nature. She is a woman who has broken the laws of her society in a wild love affair; she gives way to fits of rage and grief in the privacy of her boudoir. Only a strict constraint - imitative of the very laws she has broken - allows her to keep up the front of gentility she shows the world. Just as society and its laws by suppressing natural impulse and desire until they explode in unnatural violence, produce the spontaneous combustion that is the symbolic climax of the Chancery half of the novel, so in Lady Dedlock herself the pressure exerted by Tulkinghorn combined with her own characteristic restraint finally results in a murderous explosion of violence."

(Stoehr: 105)

When she found Lady Dedlock in the forest sitting next to her and enquired her if she was improved from her illness. It was the time after Esther had been healthier from an illness for which Lady Dedlock desired to see her daughter. They talked:

“You are recovering again? She asked kindly. 'I was quite well but a moment ago, Lady Dedlock.' Is this your young attendant?' 'Yes' 'Well you send her on before, and walk towards your house with me?"

(Bleak House: 564)

Thus, Lady Dedlock would like to speak with Esther in the absence of Miss Charley, her attendant who accompanied Esther. Esther said her to go ahead of them and they would follow her straight. Esther narrated:

"When she was gone, Lady Dedlock sat down on the seat beside me. I cannot tell in any words what the state of mind was, ........there seemed to be nothing but our two troubled minds that was not at peace."

(ibid: 565)

Thus, Esther's desire for her mom who existence was never known since her birth had finished this instant of which she met a lady surprisingly, who was none other than that her real mother. This finished her sad life as an orphan. Then, she would need to know her true father as her mother had to tell her the secrets which had been kept for many years. Her mom had an illegal relation with Captain Hawdon in which Esther became "the illegitimate fruit" (Spilka: 70) of them. "Lady Dedlock dies spectacularly beside the unmarked tomb of her lover, dressed in her maid's clothes."

(Mei Chin: 75)

Such type of child- parent relationship found between Lady Dedlock and Esther as mother- daughter relationship, the urge of the illegal child for recognizing her parents' identity and the revelation and suspension.

\section{Esther Summerson and Mr. Allan Woodcourt}

Again, there is another personal relationship found between Esther, the protagonist and Mr. Allan Woodcourt, who was a surgeon on board ship was always busy throughout the story. They met in the Bleak House where Mr. John Jarndyce, Ada and Esther lived together. Esther was somewhat predicted by Mrs. Woodcourt for her son, Allan Woodcourt 
when her son stayed to meet her godparent, Mr. Jarndyce, brought her with her son for the first time. She was an old lady who came from Wales and she was a renowned individual for an antecedent of the name of Morgan ap-Kerrig. At farewell time, Mr. Allan Woodcourt left some florae through Caddy as if Miss Esther would take the same as a token of love proposal. From that day, the flowers had been dried between the book pages as the herbarium. One day, Esther and Mrs. Woodcourt talked clandestinely for Mrs. Woodcourt expressed indirectly her proposal to be the wife of her son who would probably be Miss Esther. They talked:

"Shall I tell you what I always think of you, and the fortune yet to come for you, my love?' said Mrs. Woodcourt. And nobody, my love will congratulate you more sincerely, on such a marriage than I shall."

(Bleak House: 470)

From that minute, Esther would think that Mrs. Woodcourt was a story-teller on the one side and a sly on the other. However, Esther had begun to think of Mr. Woodcourt for she needed to be a moral wife for him. "She is as aware of Allan Woodcourt's attentions as of his intentions. And when her beauty is taken away by smallpox, she is grieved." (Mei Chin: 68)

Her love was kept as secret from him, and she would never disclose her feeling to anyone. She believed herself of his wanted and beloved that she had been planned by him. She narrated:

"And now I must part with the little secret I have thus far tried to keep. I had thought, sometimes, that Mr. Woodcourt loved me; ........ freely released him from his bondage to one whom he had never seen!"

(Bleak House: 557)

Her love for Allan was massive but she had been waiting for Allan's love proposal and marrying her. Now, the day when Mr. Allan would express his love for her has come at the usual meeting place. This time, Mr. Wood court came to see Mr. Jarndyce but as he was out for some works, Mr. Wood court anticipated Esther to walk to home with her. They spoke inside the house, standing near the window, through which they were seeing down the street. Esther came to know from the talk in an instant that Mr. Wood court loved her. But she first believed that it was too late. She pleaded him. She, then stated that she need to think of being worthier of Allan's love, and his affection. She desired to accept his proposal and had also wanted him to tell that he loved her. She said:

"And never believe, dear, dear Woodcourt, never believe that I forget this night; or that while my heart beats, it can be insensible to the pride and joy of having been believed by you."

(ibid: 890)

Then, Mr. Woodcourt kissed her hand. She then said to him:

'Mr. Woodcourt.' Said I, 'you will be glad to know from my lips before I say Good night, that in the future, ......... I am to bound by every tie of attachment, gratitude, and love, that nothing I could do in the compass of a life could express the feelings of a single day."

(ibid: 890-891) 
They expressed their emotions and made their love bond strong. They then bade Good night for that day until they met the next day. Their love destination had come as one day and her guardian, Mr. Jarndyce invited by her to come to the place in the nation where her guardian lived. There, he settled a house for Esther especially to be offered as a gift for her on the marriage eve with Mr. Allan Woodcourt. "Esther marries Allan Woodcourt, a doctor, and settles in Yorkshire. But her home, like her home before it, is called Bleak House. And both iterations of Bleak House, though cheerful in décor, with always recall the misery of their origins."

(Mei Chin: 75)

She was especially called for the marriage proposal made by Mr. Woodcourt, who had been her lover. He gave her a surprise with the marriage proposal for which Mr. Jarndyce educated their relation from Mr. Allan. He was then continued talking about their relationship between Mr. Allan and her since a long period. He said:

“Hush, little woman! Don't cry! This is to be a day of joy. ........ and will sacrifice it so completely, so entirely, so religiously, that you should never suspect it, though you watched her night and day."

(Bleak House: 914)

Then, Mr. Jarndyce raised affectionately Esther's head and kissed her in his old fatherly manner again and again. Here, the relationship between Esther and Mr. Jarndyce, as Esther had been raised from her childhood after her guardian died by Mr. Jarndyce, and when she became ill seriously and lost her attractiveness. Mr. Jarndyce anticipated her and was reciprocated, and now the parent- child relationship turns momentarily into lovers' relationship.

In this background, Jacob remarks in his introduction that "A marriage between Esther and Jarndyce would have been a possible denouement; but the whole action of their courtship and engagement is made into a puzzling irrelevancy by her marriage to Woodcourt."

(Korg: 19)

However, the writer would not detriment this child - parent relationship easily and when Mr. Jarndyce realized that Esther has indeed a lover who would marry her and make him a good husband. He (Mr. Jarndyce) then told them that giving Bleak House as a gift for Esther:

"One more last word when Allan Woodcourt spoke to you, my dear, This day I give this house its little mistress; and before God, it is the brightest day in all my life!"

(Bleak House: 914)

He then raised Esther with him telling that Esther is not alone and now she had her husband, Allan. He handed Esther to Allan after that saying:

"Take from me a willing gift, the best wife that ever man had. What more can I say to you, than that I know you deserve her! ....... and what do I sacrifice? Nothing, Nothing."

(ibid: 915)

In this situation J. Hillis Miller comments 
"The marriage of Allan and Esther is the marriage of two people who have no imposed ties with one another, and who freely choose one another. Final happiness for Esther can come not through her own efforts alone, but through Allan Woodcourt's voluntary surrender of all social determination of his choice of a wife. It is the liberating act of love. But even love does not break the law of Dickens' moral world which says that there is no ceasing to be the self one already is no transformation with impunity into an entirely new self. Allan's love transforms Esther not by making her cease to be illegitimate and therefore socially alienated, but by choosing her as she is. The novel ends with a scene in which Allan tells Esther that the disfiguration of her face, caused by her illness, and the symbolic sign of her illegitimacy, has made her "prettier than [she] ever [was]."

(Miller: 223)

The relationship between Mr. Allan Woodcourt and Esther in the story is one of the most significant relationships in the novel.

\section{CONCLUSIONS}

The conclusion of our critical valuation of the famous English novelist, Charles Dickens will never be an easy job. $\mathrm{He}$ is a social reformer as well as a benevolent novelist. He built his plans found among the English people of London city and their associations which became universal significance, ultimately. His tales offer a vivid and fine scene of London life which advanced after fast industrial rebellion of England. Arthur Compton-Rickett has truly observed thus:

"The novel provides such a facile and attractive means of popular appeal, and is so adaptable to literary fashions, that its continued vitality will surprise no one."

(Compton-Rickett, 2012:661-662)

Charles Dickens along with W.M. Thackeray, his contemporary can offer a new genre of fiction for the covers all over the globe. Even though Charles Dickens depicted the London life of his age, his fame was not limited to England. It was of worldwide significance.

His age was an age of industrial revolution, hence the life in London was very rigid with the fast changes happening in England. He knew the hard truths of life of the nation thereby, made him to portray these images to reform it to make a supportable atmosphere by awakening the eyes of authority. His stories have numerous characters starting from childhood to manhood as a society includes children, women, men and other elderly people. In his novel, all these characters can be seen. So, in such a condition, the human associations have been invented throughout the stories. We are aware that one generation is substituted by another generation, and society starts from a child raising to manhood and womanhood to find a generation, which is seen in most of his stories. He had experienced the hard life during his childhood and this is his main concept of novels. Several children are depicted in his stories as a society includes children and women and men together. To quote W.R Goodman's comment:

"In the crowd of human beings that throng these books there are many boys and girls. Often, indeed, a novel is the story of a child growing into manhood and womanhood; and no preceding novelist had written so much of the experiences of childhood."

(Goodman, 2010: 373) 
He has created about 15 novels totally including his last unfinished novel, Edwin Drood, with readers from various parts of the globe from Russia to America. His child image is diplomatically depicted with depressed life of child as an orphan.

In the later stories of Charles Dickens, Bleak House, which is satiric in structure, is a type of novel which displays the pointless judicial system of the English society. The novel has also a lovely and an exclusive human relationship in it which the novelist portrays sensitively. The love-relationship between friends, relationship between cousins, the relationship between boarder and benefactor as found between John Jarndyce and Esther is a significant relationship portrayed in the novel.

Charles Dickens has attained high ranks of reputation through such novels, which his contemporary writers can never attain. He was famous with all English society classes thereby creating a special place for him among the writers. Examining the human relationships found in Dickens novel help us to familiarize ourselves with the kinds of people living in Dickens age and of their nature, and ambitions and help us to extend our appreciation and understanding of Dickens' novels.

\section{REFERENCES}

1. Arthur Compton-Rickett,A History of English Literature (New Delhi: Universal Book Stall, 2012)

2. Chin, Mei, On the Works of Charles Dickens in Harold Bloom (Ed.) Charles Dickens, (Philadelphia: Chelsea House Publishers, 2003)

3. Dickens, Charles, Bleak House, Edited by Norman Page with an introduction by J. Hillis Miller, (Australia: Penguin Books, 1971.)

4. Goodman, W.R. A History of English Literature. Vol.2, (Delhi: Doaba House, 2010)

5. Korg, Jacob, House. A collection of Critical Essay.(New Zealand: Prentice-Hall Inc. Englewood Cliffs, 1968)

6. Miller, J. Hillis, Charles Dickens The world of His novels, (Cambridge, Massachusetts: Havard University Press, 1958)

7. Stoehr, Taylor. Dickens: The Dreamer's Stance. (Ithaca: Cornell. U.P., 1965) 
